\title{
Surgical treatment of displaced intraarticular calcaneus fractures using anatomical lateral frame plate
}

\author{
İrfan Esenkaya, M.D., ${ }^{1}$ Fatih Türkmensoy, M.D., ${ }^{2}$ Bahattin Kemah, M.D.,, ${ }^{3}$ Oğuz Şükrü Poyanlı, M.D. ${ }^{1}$ \\ ${ }^{1}$ Department of Orthopaedics and Traumatology, İstanbul Medeniyet University, Göztepe Training and Research Hospital, İstanbul-Turkey \\ 2Department of Orthopaedics and Traumatology, Afyon Dinar State Hospital, Afyon-Turkey \\ ${ }^{3}$ Department of Orthopaedics and Traumatology, Ağrı State Hospital, Ağrı-Turkey
}

\begin{abstract}
BACKGROUND: The present study evaluated the results obtained from the anatomical lateral frame plate treatment of displaced intraarticular calcaneus fractures.

METHODS: Overall, I 4 displaced intraarticular fractures of 13 patients ( 3 females, 10 males; Mean age, 37.5 years) were included in the present study. Surgery was performed using widened lateral approach and supported by auto grafts following joint line reduction in all patients. They were then fixated by anatomical lateral frame plate. All the joints were stabilized by casting after the operation. All patients were prescribed controlled and full weight bearing at $6-8^{\text {th }}$ and $12^{\text {th }}$ weeks, respectively.
\end{abstract}

RESULTS: Mean follow-up of patients was 28 months. The fractures were classified according to Sanders system. Clinical scoring of the patients was performed according to American Orthopaedic Foot and Ankle Society, Creighton-Nebraska, and Maryland systems. According to these systems, the mean scores of the patients were 83.7, 75.7, and 88.5 respectively.

CONCLUSION: In the present study, we have defined the results of anatomical lateral frame plate treatment in patients with displaced intraarticular calcaneus fractures. We have obtained clinically and radiologically satisfactory results with the anatomical compatibility of plate to the lateral surface of the calcaneus.

Keywords: Calcaneus fracture; intraarticular calcaneus fracture; lateral frame plate.

\section{INTRODUCTION}

Calcaneus, the largest of the seven tarsal bones, acts like a strong lever to direct the body weight to the ground. Many approaches have been tried in the treatment of these historically important fractures and they have been changed over time. Although conservative treatment modalities were preferred previously, they have been replaced by surgical treatment options with the development in techniques..$^{[1,2]}$

Surgical treatment of calcaneus fractures with lateral approach according to medial approach is frequently preferred because it is relatively easy to perform and less tissue damage. On the contrary, this approach has some limitations, such as inefficiency in reaching the pieces in medial aspect, calcaneus having a thin epidermal and dermal surface lining on the lateral side, and postoperatively observable corner necrosis. ${ }^{[3]}$

The aim of this study is to show that our anatomical lateral frame plate design, which we use to treat the displaced intraarticular calcaneus fractures, improve the three dimensional anatomy of calcaneus and have satisfactory clinical results.

\section{MATERIALS AND METHODS}

Overall, I 4 fractures of 13 patients who were hospitalized and underwent open reduction and internal fixation in Is-

\footnotetext{
Cite this article as: Esenkaya İ, Türkmensoy F, Kemah B, Poyanlı OŞ. Surgical treatment of displaced intraarticular calcaneus fractures using anatomical lateral frame plate. Ulus Travma Acil Cerrahi Derg 2018;24:156-161

Address for correspondence: Bahattin Kemah, M.D.

Ağrı Devlet Hastanesi, Ortopedi ve Travmatoloji Polikliniği, 04200 Ağrı, Turkey

Tel: +90 472 - 2151056 E-mail: bahattinkemah.md@gmail.com

Ulus Travma Acil Cerrahi Derg 2018;24(2):156-16I DOI: 10.5505/tites.2017.62355 Submitted: 07.01.2017 Accepted: 29.06.2017 Online: 12.02.2018

Copyright 2018 Turkish Association of Trauma and Emergency Surgery
} 
tanbul Medeniyet University Goztepe Training and Research Hospital Orthopedics and Traumatology Clinic, between January 2009 and March 2013 were included in the study. The surgeries were performed by first author or under the supervision of first author. One patient had bilateral fractures. Following the first aid in emergency department, anteroposterior and lateral X-ray images of the feet and ankles were obtained from each patient (Fig. I). Subsequently, computed tomography (CT) scans were obtained from each patient to understand the exact mechanism of fractures and to be able to perform classification (Fig. 2). Sanders system was used for calcaneus fracture classifications. The patients who had depression in posterior aspect of subtalar joint and had abnormal Bohler and Gissane angles were given appointments for surgery. The bullae that were seen during the time period spent to expect normal skin circulation were drained, and the patients who had affirmative wrinkle test underwent surgery.

The operations started by preparing the fractured calcaneus bones and ipsilateral iliac wings. Widened lateral approach was preferred (Fig. 3). Over retraction of dermal and epidermal structures was avoided, and $\mathrm{K}$-wires were used additionally for retraction to reduce the risk of corner necrosis, which

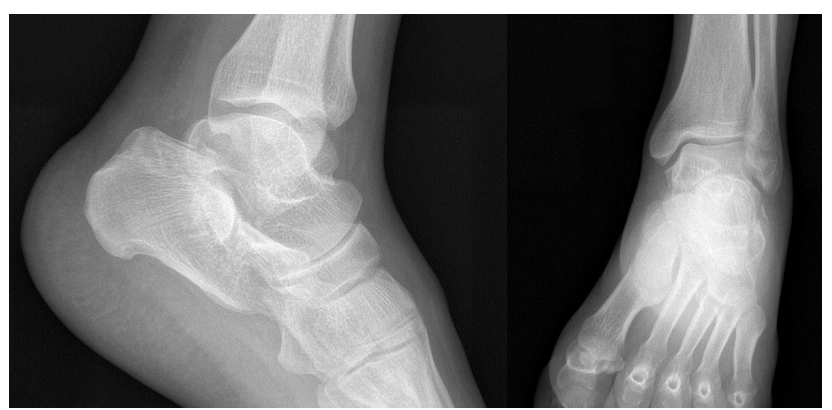

Figure 1. 42 year-old, male patient who fell down from height. Sanders Type $3 A B$ displaced calcaneus fracture. Preoperative X-ray images of left calcaneus.

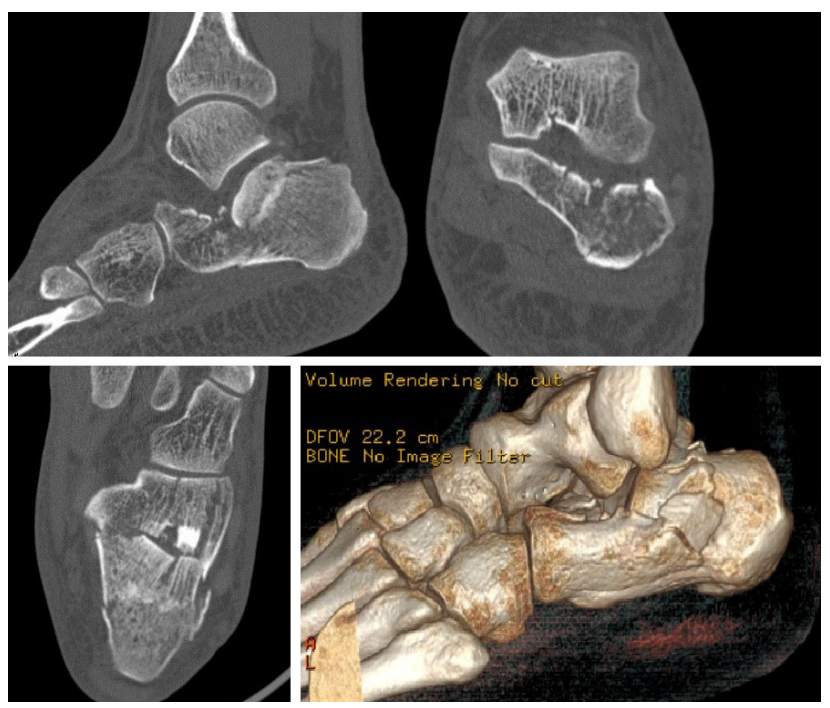

Figure 2. Preoperative CT scans and 3D images of the same patient. is an important complication after such operations. When the lateral wall of the calcaneus was reached, most of the times it was observed that a calcaneal window was formed and that its borders were well defined (Fig. 4). The depressed posterior facet joint was elevated through this window (Fig. 5). Subsequently, the joint line was visualized and reduction was performed and controlled using fluoroscopy. lliac wedge auto grafts were used to fill the gap formed because of the suppressed spongious bone beneath the posterior facet joint after elevation. Elevated posterior facet joint was supported by auto grafts from beneath and then the cortical bone window was closed.

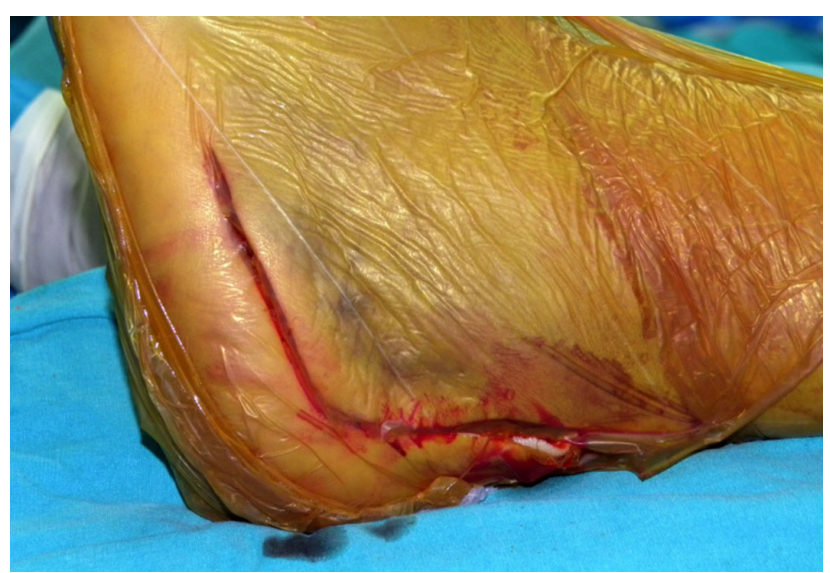

Figure 3. Widened lateral approach in the same patient.

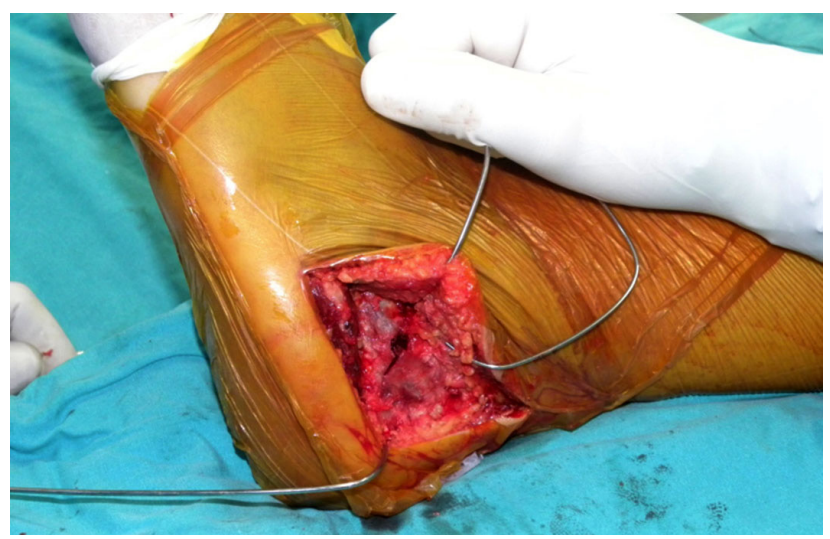

Figure 4. Deep incision and the lateral wall window. Skin necrosis is not present when retraction is performed gently, as seen in the case.

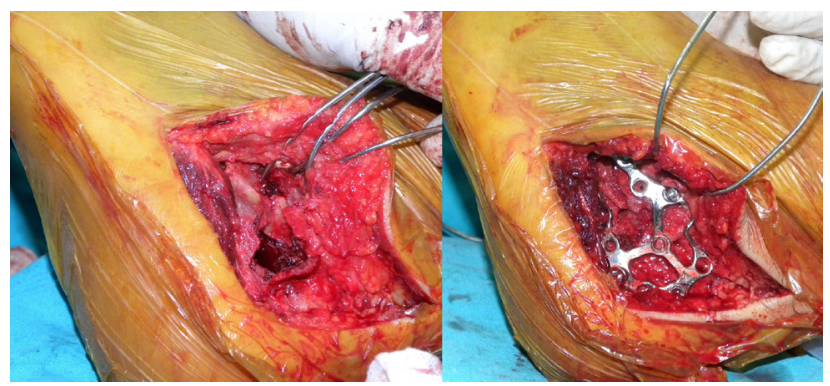

Figure 5. Depressed posterior facet joint and fixation with anatomical lateral frame plate in the same patient. 

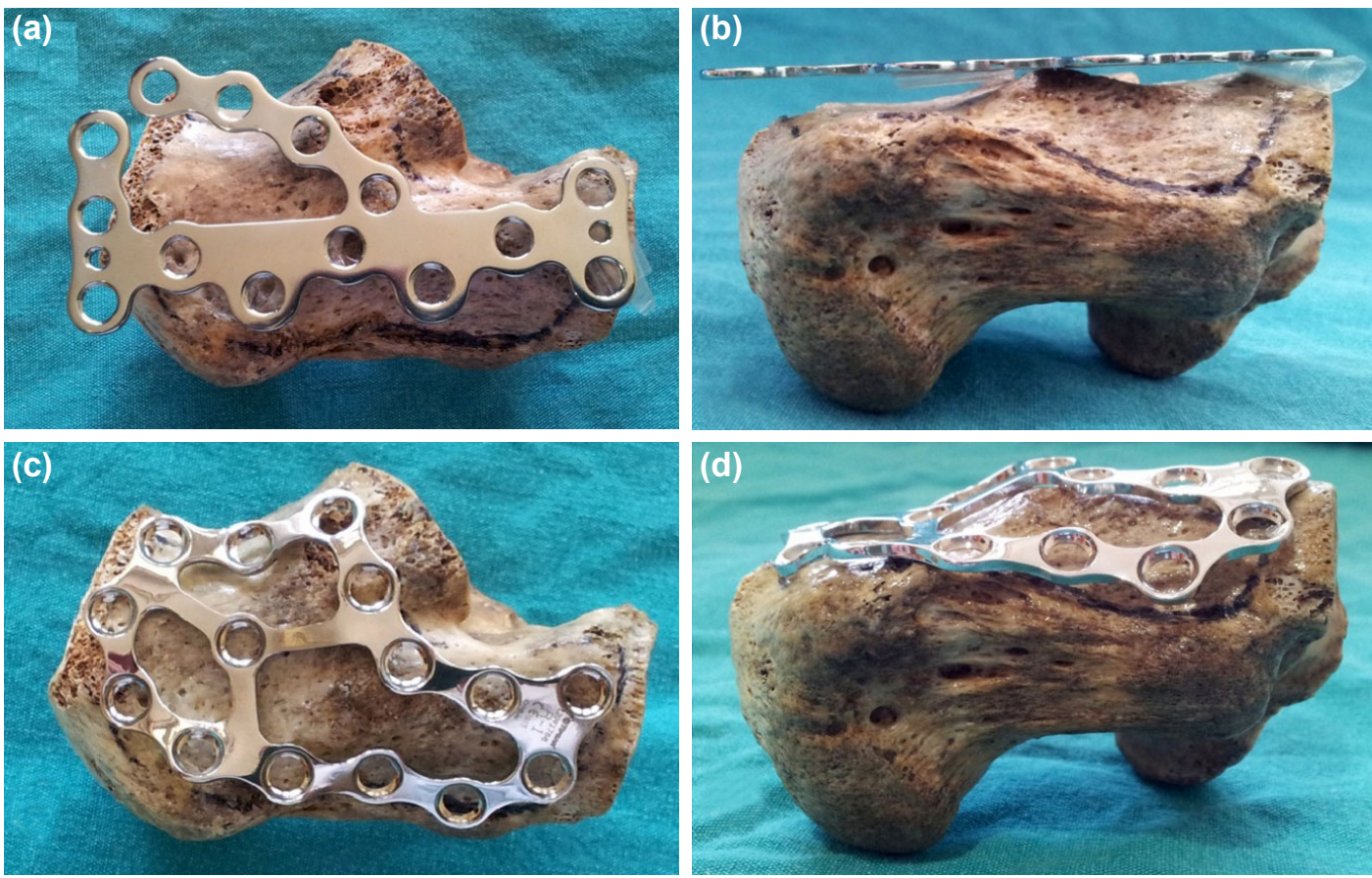

Figure 6. Anatomical plates used in our study (c and $\mathbf{d}$ ) and conventional plates ( $\mathbf{a}$ and $\mathbf{b}$ ) on real calcaneus bone.

Unlatched and low-profile anatomical frame plate, which was uniquely designed according to the anatomical structure of the lateral surface of the calcaneus by the author in first reference [Tipsan, Izmir; Patent Nr. 2010 01325], was used for reduction and fixation (Fig. 6).

Subcutaneous fat tissue and skin were closed together following the plate fixation. A drainage tube was placed to avoid hematoma formation. Casting of lower extremity of the same side was performed. X-ray and CT were performed for all patients after surgery (Fig. 7 and 8 ). The sutures were removed approximately in the following second week after examining the wound.

Following the removal of sutures, patients were prescribed active and passive ankle and subtalar joint movement exercises. Patients were allowed to supported weight bearing in $6^{\text {th }}-8^{\text {th }}$ weeks following the operation. The amount of weight was increased gradually until the $3^{\text {rd }}$ month, when the patients were allowed to bear full weight.

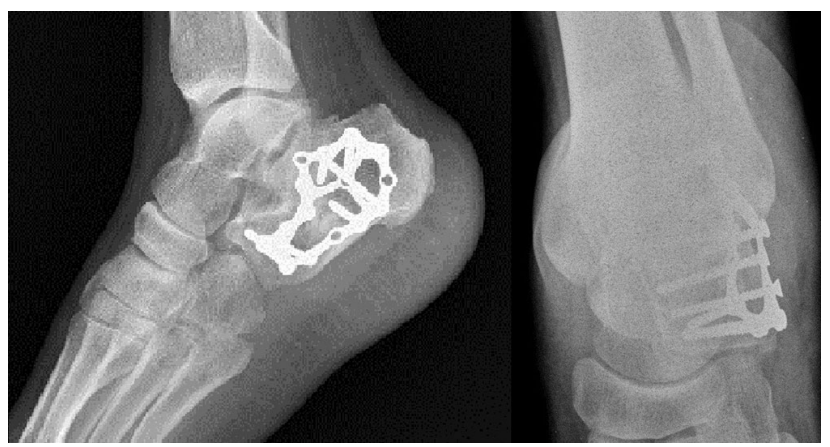

Figure 7. Postoperative X-Rays images of the same patient.
Clinical evaluation of the patients was done using American Orthopaedic Foot and Ankle Society (AOFAS), CreightonNebraska (C-N) score, and Maryland foot score systems. Data pertaining to Bohler and Gissane angles, presence of thigh and calf atrophy, any limitations to walking, limping, and period of time until working were collected for all patients before and after the operation and on their last follow-up visit.

The statistical analyses were performed using Number Cruncher Statistical System 2007 Statistical Software (Utah,

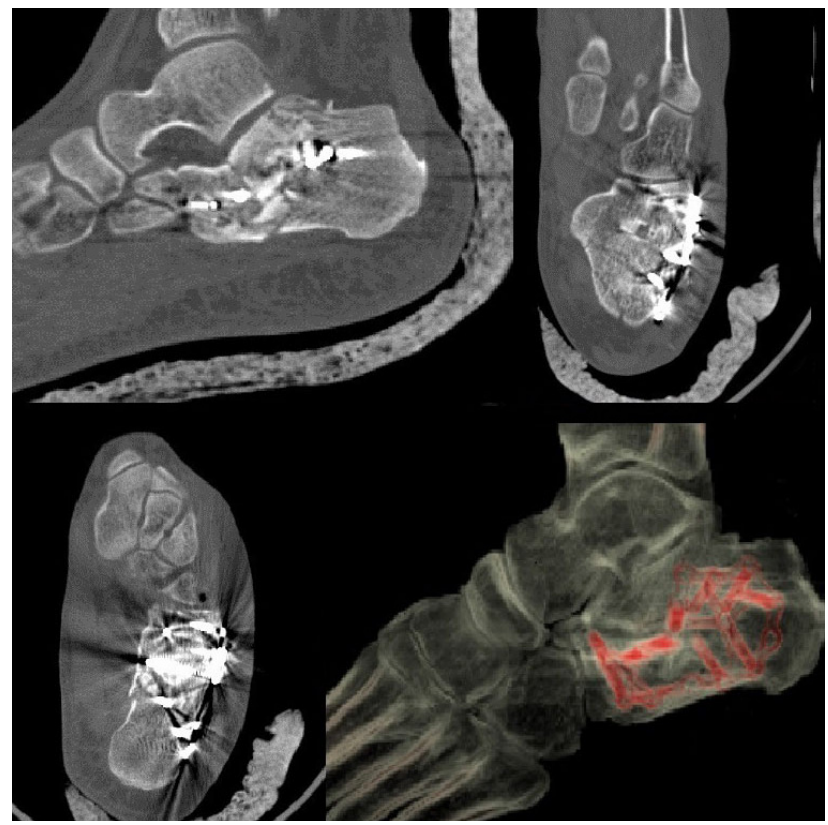

Figure 8. Postoperative CT scans and 3D images of the same patient. 
Table I. Clinical improvement and scores of the patients

\begin{tabular}{|c|c|c|c|c|c|c|c|c|c|c|}
\hline Patient & Age & Sex & Side & Type & $\begin{array}{l}\text { Waiting time } \\
\text { (days) }\end{array}$ & $\begin{array}{l}\text { Stepping } \\
\text { (weeks) }\end{array}$ & $\begin{array}{l}\text { Weight bearing } \\
\text { (weeks) }\end{array}$ & AOFAS & MARY. & C-NEB. \\
\hline A.G. & 33 & Male & Left & $3 A B$ & 2 & 6 & 9 & 79 & 90 & 88 \\
\hline A.Ç. & 42 & Male & Left & $3 A B$ & 4 & 10 & 14 & 85 & 97 & 80 \\
\hline B.Ö. & 38 & Male & Right & $3 A B$ & 2 & 12 & 24 & 88 & 89 & 78 \\
\hline B.D. & 48 & Male & Right & $3 A B$ & 8 & 8 & 14 & 87 & 94 & 85 \\
\hline C.Ç. & 46 & Male & Right & $3 A B$ & 5 & 20 & 28 & 50 & 69 & 32 \\
\hline E.G. & 26 & Male & Right & $2 A$ & 5 & 8 & 12 & 81 & 80 & 58 \\
\hline H.Ç. & $4 I$ & Female & Right & $3 A C$ & 3 & 14 & 16 & 84 & 94 & 88 \\
\hline H.B. & 39 & Male & Right & $3 A B$ & 6 & 12 & 16 & 95 & 90 & 85 \\
\hline M.B.T. & 32 & Female & Right & $2 \mathrm{~A}$ & 4 & 8 & 32 & 73 & 78 & 63 \\
\hline M.A. & 36 & Male & Right & $3 A C$ & 3 & 8 & 12 & 90 & 97 & 80 \\
\hline M.C.D. & 52 & Male & Right & $2 B$ & 12 & 12 & 16 & 90 & 93 & 95 \\
\hline N.G. & 27 & Female & Left/Right & $3 A C / 2 B$ & 4 & 14 & 24 & 92 & 90 & 78 \\
\hline Ş.K. & 39 & Male & Left & $3 A B$ & 5 & 16 & 20 & 86 & 89 & 73 \\
\hline
\end{tabular}

USA) software. The data were compared using Friedman test, Dunn's multiple comparison analysis, Mann-Whitney $U$ test, chi-square, and Fisher's test. $P$ values lower than 0.05 were accepted as statistically significant.

\section{RESULTS}

Of the I 3 patients ( 14 calcaneus fractures), 3 (23.07\%) were females and $10(76.93 \%)$ were males. All of them had closed fractures. One female patient had bilateral fractures. In all the patients, the mechanism of injury was fall from the height. The mean age of all patients was 37.5 years (26-52 years). Four of the fractures $(28.52 \%)$ were on the left, while ten of them (71.48\%) were on the right side. One patient had tibia pylon fracture on the contralateral ankle. This patient underwent open reduction and plate fixation during the same session. The mean follow-up period was 28 months (12-56 months).

According to Sanders system, seven fractures (50\%) were Type 3AB, three (21.4\%) were Type 3AC, two (14.3\%) were Type 2B, and two (14.3\%) were Type $2 \mathrm{~A}$.

Mean period of time between trauma and operation was 4.7 days (2-12 days); between operation and postoperative partial weight bearing (stepping) with the help of crutches was I I.5 weeks (6-20 weeks), and full weight bearing was 18.6 weeks (9-32 weeks). In clinical evaluation of the patients, mean AOFAS, Maryland, and C-N scores were 83.7 (50-95), 88.57 (69-97), and 75.79 (32-95), respectively (Table I).

Bohler angle means calculated before and after operation and on the last follow-up showed statistically significant improvement $(p=0.0001)$. Preoperative Bohler angle means were significantly narrower than those of postoperative and on last follow-up calculations $(p=0.002, p=0.001$, respectively); however, Bohler angles that were calculated right after the surgery and on the last follow-up did not show any statistically significant changes.

A statistically significant improvement was observed in patients' Gissane angles when preoperative and last follow-up values were compared $(p=0.002)$. Preoperative Gissane angle means were significantly narrower than those of postoperative and on last follow-up calculations $(p=0.019, p=0.013$, respectively); however, Gissane angles that were calculated right after the surgery and on the last follow-up did not show any statistically significant changes.

There was no statistically significant difference between thigh diameters of healthy and traumatic legs $(p=0.14 I)$. There was no statistically significant difference between calf diameters of healthy and traumatic legs $(p=0.098)$.

There was no significant difference between the mean ages of Sanders Type 2 and Sanders Type 3 groups $(p=0.228)$. There were no significant differences in periods of resting (days), limited weight bearing (weeks), full weight bearing and starting to work (weeks) times between Type 2 and 3 fracture types of patients $(p>0.05)$ (Table I).

AOFAS, Maryland, and C-N improvement percentages did not give any statistically significant results between Type 2 and 3 patients $(p>0.05)$. In addition, there were no statistically significant differences between these two groups in following aspects: means of Bohler and Gissane angles $(p>0.05)$ and thigh and calf diameters compared to those of the healthy legs.

All patients returned to their previous jobs, except for one 
patient who needed some improvement in working conditions because of pain. All patients are able to walk without any limitation arising from calcaneal fractures.

Because the plate is produced in the production phase in such a way that it can be anatomically compatible with the bone surface, its application and fracture reduction are easy to fix.

\section{DISCUSSION}

For the treatment of calcaneal fractures, there have been many options from conservative to open surgical techniques. In literature, the first conservative treatment choice technique of these fractures, suggested by Herman, was the disimpaction, in which the deformity was corrected under general anesthesia by hitting the lateral surface of calcaneus with a wooden hammer after placing a towel on the skin. ${ }^{[4]}$ Herman's aim was to achieve the original height of the calcaneal bone. He believed that this technique would restore the functions of the heel and back of the foot.

The studies that assess the use of conservative treatment showed that these patients may have had pain after prolonged physical activity even if they can go back to work after treatment. Walking analyses performed on these patients also support this result. ${ }^{[5,6]}$ However, when the conservative treatment is compared to surgical options, there was no statistically significant difference between them. ${ }^{[7]}$

In another study that gave priority to conservative treatment, in patients who had segmental fractures that cannot be treated conservatively, they tried conservative treatment first. Subsequently, corrective osteotomy and arthrodesis were performed to treat the remaining complaints. When the results were evaluated, it was well understood that earlier surgery, which was performed before the malunion developed, had given better results. ${ }^{[8]}$

The use of grafts is another contradictive topic on the treatment of these fractures. Studies show that patients in whom grafts were involved gave better and more satisfactory results with earlier full weight bearing than without using greft. ${ }^{[2,9-11]}$

Minimally invasive and fixation by screw onto the percutaneous canulla techniques were tried to avoid complications such as corner necrosis, infections, and osteomyelitis arising from surgical treatment of calcaneus fractures, and they gave satisfactory results. However, it was stated that these treatment modalities could only be used in moderate fractures in which the conservative treatment would not be insufficient and the open surgery would be too invasive because displaced fractures with many segments cannot be reduced externally. ${ }^{[12-14]}$

Sanders classification is a system that is frequently used in calcaneal fractures and it also predicts the prognosis. Type I fractures often give more satisfactory results, the other high grade types of fracture result have more unfavorable outcomes. Therefore, some authors defend the idea that surgical techniques should only be used in moderate-class fractures (i.e., excluding types I and 4). ${ }^{[15]}$

When kinematic data of the feet and ankles were assessed after conservative and surgical treatment of calcaneal fractures, there was no statistically significant difference between healthy and fractured extremities in both groups. ${ }^{[6,17]}$ In another study evaluating cost effectiveness of these two options, it was observed that surgical treatment of these fractures is both more effective and cheaper than conservative treatment methods. ${ }^{[18]}$

In accordance with the developments in surgical techniques and biomechanics, nowadays, surgical treatment is usually the first choice in calcaneus fractures. In literature, the aims of the surgical treatment are defined as follows: I) Reducing the posterior facet joint, 2) Providing original height and width of calcaneus, 3) Achieving fibular tendon mobility, 4) Regaining the valgus position of tuber calcanei, and 5) Reducing the calcaneo-cuboidal joint. ${ }^{[14,15]}$

The authors who support the open reduction and internal fixation in recent studies emphasize that cases that are treated surgically have more positive feedbacks, that the patients in which the surgery is chosen as the first treatment option have better outcomes, and that these patients have higher long term quality of life. ${ }^{[14,17,19,20]}$

\section{Conclusion}

The results of our study are similar to those in the literature in that patients with displaced intraarticular calcaneal fractures benefit from open reduction and internal fixation. When all patients are evaluated, the statistically significant difference of Bohler and Gissane angles before and after the operation indicates that the technique is satisfactory in correction; patients having no difference in Bohler and Gissane angles measured after the operation and on the last follow-up (mean, 28 months) shows that the anatomical lateral frame plate has sufficient fixation feature.

This statistically significant improvement in all the patients is also observed in Sanders Type 2 and Type 3 fractures, and this shows the success of open reduction and fixation with an anatomical plate.

There is still no common treatment modality for calcaneal fractures in literatures; however, the current approaches favor conservative management in fractures that lack displacements and deterioration in the dimensional configuration of the calcaneal bone, while surgery is preferred in cases with depression on joint surfaces, particularly on posterior facet joint, or with changes in height, width, or lining of calcaneus. The most common surgical approach is widened lateral approach. There are many materials developed for fixation after the reduction 
of joint and fracture line. The anatomical lateral calcaneus plate, which is shaped in accordance with the anatomical structure of the lateral surface of the calcaneus, fits to the lateral aspect of the bone very well. It also reduces the risk of necrosis and it does not disturb the patients with its well-fitting screws to the holes; therefore, it does not form any bulges in this area, which has a very thin skin and delicate circulation. This and other aforementioned features make the anatomical lateral calcaneus plate advantageous compared to other fixation materials.

Conflict of interest: None declared.

\section{REFERENCES}

1. Sanders R. Displaced intra-articular fractures of the calcaneus. J Bone Joint Surg Am 2000;82:225-50. [CrossRef]

2. Gülabi D, Sarı F, Sen C, Avcı CC, Sağlam F, Erdem M, et al. Mid-term results of calcaneal plating for displaced intraarticular calcaneus fractures. Ulus Travma Acil Cerrahi Derg 2013;19:145-51. [CrossRef]

3. Muñoz F, Forriol F. Current management of intra-articular calcaneal fractures. Rev Esp Cir Ortop Traumatol 2011;55:476-84.

4. Herman OJ. Conservative therapy for fracture of the os calcis. J Bone Joint Surg 1937;19:709-18.

5. Barnard L, Odegard JK. Conservative approach in the treatment of fractures of the calcaneus. J Bone Joint Surg Am 1970;52:1689. [CrossRef]

6. Kitaoka HB, Schaap EJ, Chao EY, An KN. Displaced intra-articular fractures of the calcaneus treated non-operatively. Clinical results and analysis of motion and ground-reaction and temporal forces. J Bone Joint Surg Am 1994;76:1531-40. [CrossRef]

7. Buckley R, Tough S, McCormack R, Pate G, Leighton R, Petrie D, et al. Operative compared with nonoperative treatment of displaced intraarticular calcaneal fractures: a prospective, randomized, controlled multicenter trial. J Bone Joint Surg Am 2002;84-A:1733-44. [CrossRef]

8. Clare MP, Lee WE 3rd, Sanders RW. Intermediate to long-term results of a treatment protocol for calcaneal fracture malunions. J Bone Joint
Surg Am 2005;87:963-73. [CrossRef]

9. Palmer I. The mechanism and treatment of fractures of the calcaneus; open reduction with the use of cancellous grafts. J Bone Joint Surg Am 1948;30A:2-8. [CrossRef]

10. Horn CE. Fractures of the calcaneus. Diagnosis and treatment. Calif Med 1968;108:209-15.

11. Yang Y, Zhao H, Zhou J, Yu G. Treatment of displaced intraarticular calcaneal fractures with or without bone grafts: A systematic review of the literature. Indian J Orthop 2012;46:130-7. [CrossRef]

12. Levine DS, Helfet DL. An introduction to the minimally invasive osteosynthesis of intra-articular calcaneal fractures. Injury 2001;32 Suppl 1:SA51-4. [CrossRef]

13. Tomesen T, Biert J, Frölke JP. Treatment of displaced intra-articular calcaneal fractures with closed reduction and percutaneous screw fixation. J Bone Joint Surg Am 2011;93:920-8. [CrossRef]

14. Kayalı C, Altay T, Kement Z, Çıtak C, Yağdı S. The effect of early weightbearing on comminuted calcaneal fractures treated with locking plates. Eklem Hastalik Cerrahisi 2014;25:85-90. [CrossRef]

15. Jain V, Kumar R, Mandal DK. Osteosynthesis for intra-articular calcaneal fractures. J Orthop Surg (Hong Kong) 2007;15:144-8. [CrossRef]

16. Hetsroni I, Nyska M, Ben-Sira D, Arnson Y, Buksbaum C, Aliev E, et al. Analysis of foot and ankle kinematics after operative reduction of highgrade intra-articular fractures of the calcaneus.J Trauma 2011;70:1234-40.

17. Potter MQ, Nunley JA. Long-term functional outcomes after operative treatment for intra-articular fractures of the calcaneus. J Bone Joint Surg Am 2009;91:1854-60. [CrossRef]

18. Brauer CA, Manns BJ, Ko M, Donaldson C, Buckley R. An economic evaluation of operative compared with nonoperative management of displaced intra-articular calcaneal fractures. J Bone Joint Surg Am 2005;87:2741-9.

19. Radnay CS, Clare MP, Sanders RW. Subtalar fusion after displaced intra-articular calcaneal fractures: does initial operative treatment matter? J Bone Joint Surg Am 2009;91:541-6. [CrossRef]

20. Agren PH, Wretenberg P, Sayed-Noor AS. Operative versus nonoperative treatment of displaced intra-articular calcaneal fractures: a prospective, randomized, controlled multicenter trial. J Bone Joint Surg Am 2013;95:1351-7. [CrossRef]

\section{ORIJjINAL ÇALIŞMA - ÖZET}

\section{Deplase eklem içi kalkaneus kırıklarının anatomik lateral çerçeve plak kullanılarak cerrahi tedavisi}

\section{Dr. İrfan Esenkaya, ${ }^{1}$ Dr. Fatih Türkmensoy, ${ }^{2}$ Dr. Bahattin Kemah, ${ }^{3}$ Dr. Oğuz Şükrü Poyanlı ${ }^{1}$}

${ }^{1}$ İstanbul Medeniyet Üniversitesi Tıp Fakültesi, Göztepe Eğitim ve Araştırma Hastanesi, Ortopedi ve Travmatoloji Anabilim Dalı, İstanbul ${ }^{2}$ Afyon Dinar Devlet Hastanesi, Ortopedi ve Travmatoloji Kliniği, Afyon

${ }^{3}$ Ağrı Devlet Hastanesi, Ortopedi ve Travmatoloji Kliniği, Ağrı

AMAÇ: Bu çalışmanın amacı deplase eklem içi kalkaneus kırıklarının tedavisinde uyguladığımız anatomik lateral çerçeve plak sonuçlarını değerlendirmektir. GEREÇ VE YÖNTEM: Çalışmaya 13 hastanın (3 kadın, 10 erkek, ortalama yaş: 37.5 ) 14 deplase eklem içi kırığı olan hasta alındı. Tüm hastalara genişletilmiş lateral yaklaşım uygulandı ve eklem hattı redükte edildikten sonra otogreft kullanılarak desteklendi. Daha sonra da anatomik lateral çerçeve plak ile tespit edildi. Ameliyattan sonra tüm hastalara atel uygulandı. Ameliyattan sonra hastalara 6-8. haftalarda kontrollü, 12. haftadan sonra ise tam yük verdirildi.

BULGULAR: Hastaların ortalama takip süresi 28 aydı. Kırıkların sınıflaması Sanders sistemine göre yapıldı. Hastaların klinik skorlamaları AOFAS, Creighton-Nebreska ve Maryland skorlama sistemleri kullanılarak yapıldı. Hastaların bu skor sistemlerine göre ortalaması sırası ile 83.7, 75.7, 88.5 olarak bulundu.

TARTIŞMA: Çalışmamızda deplase eklem içi kalkaneus kırı̆̆ı olan hastalarda kullandı̆̆ımız anatomik lateral çerçeve plak tasarımımızın sonuçlarıı tanımladık. Kullandığımız plağın kalkaneusun lateral yüzüne anatomik olarak oturmasıyla hem klinik hem de radyolojik olarak yeterli ve tatmin edici sonuçlar elde ettik.

Anahtar sözcükler: Eklem içi kalkaneus kırı̆̆ı; kalkaneus kırı̆ı̆; lateral plaklama.

Ulus Travma Acil Cerrahi Derg 20|8;24(2):156-161 doi: 10.5505/tites.2017.62355 